
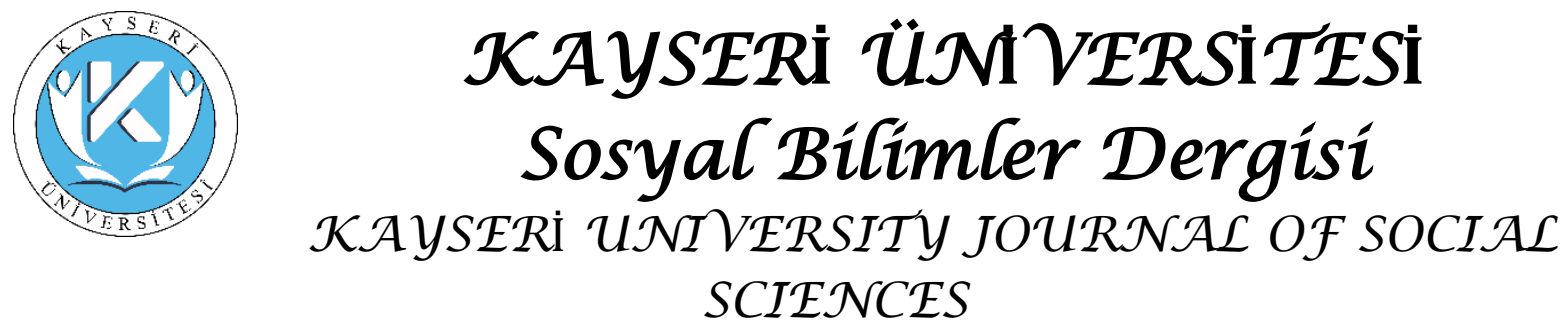

\begin{tabular}{|l|l|l|l|l|l|}
\hline Makale Türü & Araştırma makalesi & Yıl & $\mathbf{2 0 2 1}$ & ss. & $\mathbf{1 - 9}$ \\
\hline Gönderi Tarihi & $\mathbf{3 1 . 0 3 . 2 0 2 1}$ & Cilt & $\mathbf{3}$ & DOI & $\mathbf{1 0 . 5 1 1 7 7 / k a y u s o s d e r . 9 0 7 4 1 4}$ \\
\hline Kabul Tarihi & $\mathbf{2 4 . 0 6 . 2 0 2 1}$ & Say1 & $\mathbf{1}$ & & \\
\hline Online Yayın Tarihi & $\mathbf{3 0 . 0 6 . 2 0 2 1}$ & Ay & Haziran & & \\
\cline { 1 - 3 } & & &
\end{tabular}

\title{
Sosyal ve kültürel faktörlerin etkisi altında Jorge Luis Borges'in “El Sur” (Güney) isimli kısa öyküsünün Türkçe ve İngilizce çevirilerinin karşılaştırmalı çözümlemesi*u
}

\section{Comparative analysis of Jorge Luis Borges' short story "El Sur" in Turkish and English translations under the influence of social and cultural factors}

$\ddot{\mathbf{O} z}$

Bu çalışma Arjantinli yazar Jorge Luis Borges’in 'El Sur' (Güney) isimli hikâyesinin İspanyolca aslından Türkçe ve İngilizceye yapılan çevirilerini sosyal ve kültürel etkenleri de göz önünde bulundurarak karşılaştırmalı bir çözümleme yapmayı hedeflemektedir. Çevirmenler kaynak ve erek kültürlerin özelliklerini tahlil ederek yeri geldiğinde ekleme yeri geldiğinde eksiltme vb. yollarla bu hikâyeyi kendi dillerine kazandırmışlardır. Kültürlerarası zenginliğin artması ve iletişimin ilerleyebilmesi için yapılan çeviriler farklı dünyaların birbirlerine ev sahipliği yapmasına olanak tanır. Edebi hayatı boyunca metafiziksel, fantastik ve tamamen sübjektif ürünler ortaya çıkaran Borges, büyülü gerçekçilik akımının öncelikli isimleri arasında yerini almıştır. Böylesine düşünceleri ve kalemi kuvvetli bir yazara ait öykünün tahlilinde ilk olarak kültürlerarasılık konusundan bahsedeceğiz, hemen ardından bahsi geçen hikâyenin Türkçe ve İngilizce çevirileri üzerine karşılaştırmalı bir analiz yapacağız. Çeviride yaşanan kültürel ve sosyal etkenlerin aktarımda yarattı̆̆ı sıkıntılar, kaynak ve erek kültürlerin birbirleriyle olan ya da olmayan etkileşimleri makalemizin çıkış noktalarını oluşturacaktır.

Anahtar Kelimeler: Jorge Luis Borges, El Sur, Çeviri, Çeviri Sorunsalları, Kültürlerarasılık

Abstract

This study aims to make a comparative analysis of the translation of 'El Sur' (South) by Jorge Luis Borges from the original Spanish to Turkish and English, taking into account the social and cultural factors. The translators analyze the properties of the source and target. The translation of intercultural richness and the translation of communication allows different worlds to host each other. Borges, which produced metaphysical, fantastic and completely subjective products throughout his literary life, has taken its place among the top names of the magical realism movement. We will first talk about the interculturalism, and then we will make a comparative analysis on the Turkish and English translations of the mentioned story. The problems created by the cultural and social factors in translation and the interactions between the sources and the target cultures will be the starting points of our article.

Key Words: Jorge Luis Borges, El Sur, Translation, Translation Problems, Interculturalism

\footnotetext{
${ }^{\Delta}$ Yazarlar bu çalışmanın tüm süreçlerinin araştırma ve yayın etiğine uygun olduğunu, etik kurallara ve bilimsel atıf gösterme ilkelerine uyduğunu beyan etmiştir. Aksi bir durumda Kayseri Üniversitesi KAYÜSOSDER Dergisi sorumlu değildir.

*Etik kurul izni gerektirmeyen çalışmalardandır.

${ }^{1}$ Öğretim Görevlisi, Ankara Sosyal Bilimler Üniversitesi, Yabancı Diller Yüksekokulu, Yabancı Diller Bölümü, ortacneslihan@gmail.com
} 
Ortaç, $\mathcal{N}$. (2021). Sosyal ve kültürel faktörlerin etkisi altında Jorge Luis Borges'in "If Sur" (Güney) isimli kisa öyküsünün Türkçe ve ingilizce çevirilerinin karşılaştırmali çözümlemesí.

\section{Giriş}

1899-1986 yılları yaşamış olan Arjantinli yazar Jorge Luis Borges, 20. yüzyılın yenilikçi ve önemli edebiyat figürlerinden biridir. Eserlerinde geleneksel olandan uzaklaşan tavrı ve kendine has üslubu ile öznel bir kurgusal dünya yaratmıştır. Şiirlerinde meydan okuyan, cüretkâr tarzı ve avangard hikâyeleri onu hem Latin Amerika hem de evrensel edebiyatın önde gelen isimleri arasına yerleştirmiştir.

Borges'in eserleri okuyucu tarafından hem çok sevilir hem de anlaşılması çok kolay olmadığı için düşünmeye sevk eder, hatta bazen bu sinir bozucu bir hal bile alabilir. Borges kendine has bir üsluba ve bireysel bir sembolojiye sahiptir; bu yüzden tüm dünyada birçok yazar ve edebiyat eleştirmeninde hayranlık uyandırmıştır. Bu bağlamda kendi edebiyat anlayışını şu sözlerle belirtmiştir:

Ne filozofum ne de bir ahlakçı, sadece edebiyat şeklini verdiğimiz ve adına felsefe dediğimiz saygıdeğer karmaşıklıklar sistemini ve kendi karmaşıklığını yazılarına yansıtan bir edebiyat adamıyım' (Ruiz Pérez, 2016, s. 1).

Borges'in El Sur isimli hikâyesinde kullandığı metaforlar ve hikâye içerisinde adı geçen eserlere yaptığı atıflar (Binbir Gece Masalları ve Paul ve Virginie) entelektüel ve teşvik edici bir okuma hissiyatı uyandırmaktadır. Borges, eve bir an önce gidip Binbir Gece Masalları'nı okumaya niyetlenen kahramanı Juan Dahlmann'ı yaşadığı bir kaza neticesinde hastane odasında bulmasına ve bu andan itibaren bir hayal dünyasında olayların seyretmesine zemin hazırlıyor. Sonrasında gelişen olaylar aslında hala hastane odasında yatarken gerçekleşiyor ve hala hayatta iken rüyasında iyileştiğini, bir yolculuğa çıktığını ancak inmesi gerekenden bir durak önce indiğini ve orada kendisi gibi olan yerli halktan sarhoş bir adamın onu düelloya davet etmesi ve bıçak tutmayı bilmediği halde kabul ederek elinde bıçakla ovaya doğru ilerlerken olayın bitmesi o sırada Dahlmann'ın da gerçekten öldüğünü gösteriyor. Fiziksel bedeninde yaşamı sona ermeye yaklaşmışken, zihninde hala maceralara atlaması, trene atlayıp güneydeki çiftliğin hayalini kurması ve gidişi ve en sonunda ölümle burun buruna gelerek bile isteye ona doğru yürümesi kanındaki Cermen etkisiyle romantik bir ölüm tarzını arzulamasından kaynaklanmaktadır.

Bu karmaşıklık ve aynı anda ahengin 1 şı̆̆ında bir de çeviri stratejilerini de işin içine katarak bir Borges çevirisi yapmak çok da kolay bir iş değildir elbette. Elimizde bulunan çeviri metinlerinden Türkçesini Fatih Özgüven İngilizce versiyonundan alarak yapmıştır, yani burada dolaylı bir çeviri örneği görmekteyiz. Hem Borges'in dilinin zorluğu ve Latin Amerika kültürünün ülkemizde tanınırlı̆̆ının azlığı hem de İspanyolcadan direkt çeviri yapan çevirmenlerin sayısının çok olmayışı bu hikâyenin orijinal çevirisinin elimizde olmamasının ana nedenlerini oluşturmaktadır.

Dolaylı çeviri ya da ikinci el yapılan çeviriler kimi zaman coğrafi durumlarla uzak kalmış kimi zamansa daha fazla güç ve prestij sahibi olanların diğerlerini etkisi altına alması sebebiyle kültürlerarası ilişkilerin uzun bir tarihi sürece girmesine ya da en baştan hiçbir etkileşim içerisinde bulunmamasına sebebiyet vermiştir (Marín-Lacarta, 2008, s. 1). İlk olarak ülkemizin İspanya ile olan münasebetine baktığımızda her ne kadar Latin Amerika'dan oldukça uzak ama İspanya'dan coğrafi olarak uzak olmasak da İspanyol ve Latin Amerika edebiyatlarına ait çeviri örnekleri dilimizde sayıca az bulunmaktadır. Türkçeye İngilizce ve Fransızcadan yapılan çevirilere göre İspanyolcadan yapılan çevirilerin çok az olduğu görülür. Bu sebeple var olan çevirilerin bir kısmının dolaylı olarak genellikle de İngilizceden yapıldığını belirtmek gerekir. Bu da karşımıza edebi sistemlerin ve statüler arasındaki ilişkilerin kesin bir yansıması olarak çıkmaktadır.

\section{Sosyal ve kültürel faktörler ile çeviri sorunsalları ıșığında kültürlerarasılık}

Çeviri artık dilbilimsel bir süreç olmanın ötesinde, diller ve kültürler arasında bir köprü ve diyalog, dillerin ve kültürlerin zenginliğinin yaşamasını sağlayan bir uygulamadır (Taş, 2017, s. 2). Çevirmen ise metinler, diller ve kültürlerin arasında işini icra eder ve ayrıcalıklı bir konumda yer alır. Nitekim çeviriyi nasıl yapacağına karar veren kendisidir ve alıcı olan hedef kültüre mesajları ulaştırma yetkisinin kendinde olduğunun bilincindedir. Bu aşamada yetkin olan çevirmen kendi kültürüne olduğu 
kadar erek kültür öğelerine de hâkim olmayı kendisine vazife edinmelidir. Aktarım sırasında yaşanan problemlerin en başında bu gelmektedir, çeviriye sadakat kuralını kendine görev edinmiş çevirmen aslında kendisine de bu yolla görünürlük kazandırmış olur.

Miguel Saénz'in belirttiği üzere, çevirmen kullandığı kelimeler ve tercih ettiği ifade mekanizmaları sayesinde yazarın ait olduğu toplum ve kafasında yarattığı ve yazıya döktüğü izlenimlerini hedef kültüre aktaracak kişidir (Saénz, 2009, ss. 763-771). Yazar verdiği mesajı hedef dilde yeni bir söyleme dönüştürme gücüne sahiptir. Bir başka ifadeyle, çevirmen yaratma erkini elinde bulundurmaktadır, bu bağlamda da aktardıklarının orijinal olanla bağını koparmaması için her iki dilde dilbilimsel bilgi birikimine sahip olması gerekir.

Maria Tymoczko, Enlarging translation, empowering translators isimli kitabında şu sözleri sarfetmiştir:

Dominant models of translation assume that a translator must "know" the languages and cultures involved in moving between a source text and target text, but translation in postcolonial contexts challenges this view [...] Translation does not merely reflect existing knowledge: it can precede knowledge and create knowledge (Tymoczko, 2007, ss. 189-199).

Daha önce de belirttiğimiz gibi çevirmen sadece dilleri değil aynı zamanda çevirinin gerçekleştirileceği kültürel bağlamı da bilmekle yükümlüdür. Alacağı kararların hem okuyucuda hem de metinde iyi yahut kötü sonuçları olabileceğinin farkında olmalıdır. Bu sebeple herhangi bir kelimenin veya ifadenin çevirinin nihai sonucunu etkileyebileceğini ve hakkında yazılan kültürün çok farklı görüntülerini yansıtabileceğini unutmamalıdır.

Çeviri işi, her defasında içinde tartışmaları ve karmaşıklığ ihtiyaç duyan dinamiklerle karşı karşıya gelir (Limón Aguirre, 2013, s. 93). Özellikle, Borges'in bu hikâyesinde olduğu gibi, işin içinde tanıdığımız o büyük ülkelerde yaşayan yerli halklar ve bu halklara ait gelenekler ve dilsel kullanımlar, bir başka deyişle kültürel faktörler varsa çevirmen için çeviri işi daha farklı ve biraz daha zor bir boyut kazanır. Borges de hikâyesinde Alman asıllı bir Arjantinli olan ve soyu gaucholara dayanan bir adamdan ve yine kendisi gibi olanlarla karşılaşmasından sıklıkla bahseder. Yerel halkların ortak durumu, kültürel birikimlerini çevreleyen şartlarla ve deneyimlerle birlikte aslında bir tür etik ve politik anlamda bir meydan okumadır çünkü yapılan çeviriler bu insanlar için ayrımcılık ve hor görülmeye maruz kalmalarına sebep olabilir (Limón Aguirre, 2013, s. 93). Bu ayrımcılığın olmaması için çevirmenin öncelikli işinin sadece iki dili de biliyor olduğunu bilmesi değil, kendininkinden daha farklı dünyaların da olduğunu bilmesi gerektiğidir. Çokkültürlülüğün kültürlerarası iletişime olanak tanıdığını, bu sayede diğerleriyle diyalog kurabildiğimizi ve bunu aktarırken sorumluluğun kendisinde olduğunu farkındalık ve ahlak bilinciyle taşımalıdır. Var olan her dil, her gelenek belirli bir yaşam biçiminin, bir vizyonun ve kültürel mirasın ifadesidir. Elbette altı çizilmesi gereken önemli bir nokta her toplumda birtakım sosyal ve kültürel normların olduğunu bilmek ve bu normların çevirmenin hangi çeviri stratejilerini uygulayacağına karar vereceğinde etkisinin olduğudur. Gideon Toury bu bağlamda kültürel bir ortamda çevirmen olmak için bir ön şart vardır demiştir (Toury, 1995, s. 198).

\section{Borges ve "Eı Sur” (Güney) isimli kısa öyküsünün Türkçe ve İngilizce çevirileri üzerine bir tahlil}

Oxford'un kısa tarihçe sözlügünde Borges'in adının geçtiği tek bölüm bir çeviriye yapmış olduğu yorumudur: 'Orijinal olan, çeviriye sadık kalmamıştı''; Borges çeviri ve edebi yaratım arasındaki ilişkiye dikkat çekmiştir (Kristal, 1999, s. 3). Güney isimli hikâyesinin çeviri tahliline geçmeden önce Borges'in çeviri ile ilgili düşüncelerini belirtmek faydalı olacaktır.

1. Borges'e göre çeviri bir dilden diğerine aktarım değil, aksine bazı özellikleri koruyan ve bazılarını eleyen bir metnin değişimidir. Edebi çeviri detayları korurken, dolaylı anlatım ise anlamı korur. Kaynak metnin anlamını koruyan çeviri, detayları koruyan çeviriden daha sadık olabilir. 
Ortaç, $\mathcal{N}$. (2021). Sosyal ve kültürel faktörlerin etkisi altında Jorge Luis Borges'in "If Sur" (Güney) isimli kisa öyküsünün Türkçe ve ingilizce çevirilerinin karşılaşturmali çözümlemesi.

2. Borges, çevirinin aynı dil içinde gerçekleştirilebileceğini düşünürken; bir dilden başka bir dile kopya edilmesinin mümkün olduğunu düşünür. Borges kopya kelimesini farklı bir dilde yazılmış bir metnin tüm detaylarını ve tüm yan anlamlarını içeren metinler için kullanmıştır.

3. Borges'e göre çeviri orijinalinden daha iyi olabilir. Eğer orijinal metin detay, karmaşık ve karanlık özellikler içeriyorsa eserin ana fikrine sadık olmayabilir. Burada yukarıda sarf ettiği orijinal olan çeviriye sadık kalmıştır (Kristal, 1999, s. 4) sözüyle ne ifade etmek istediğini görmekteyiz.

Tymoczko'ya göre aslında her edebi metin kendinden önce yazılanlarla sıkı bir biçimde bağlıdır ve bunun sebebini daha önceden yazılan eserlerin dilsel sözleşmeleri, türleri, yazarların üsluplarının daha sonra yazılan edebi eserler üzerindeki yadsınamaz etkisine bağlamaktadır. Bunu da "yeniden yaratım" ve "yeniden yazım" olarak tanımlamaktadır (Tymoczko, 1995, s. 12). Tymoczko'nun açıklamalarından yola çıkarak Borges' in çeviriye olan bakış açısını yeniden yaratım ve yazma olarak değerlendirmek yanlış olmayacaktır. Ona göre çeviri aynı dil içerisinde aynı metni yeniden, en baştan yazmaktır, bir başka deyişle yeniden yorumlamak ve yeni bir yorum katmaktır. Bununla birlikte, başka bir dile aktarım olarak değerlendirdiği kopya kavramı yeni bir fikir üretmemekte, olanı olduğu gibi yeni bir dilde betimlemektir.

Çevrilen metinlerin iyi ya da kötü olarak yorumlanmasından önce ilk olarak ortaya konması gereken çevirisi yapılan hedef dilde ne gibi sapmalar yapılmış ve bunların sebeplerini ortaya koymak olacaktır. Hiç kuşkusuz bir çevirmen çeviri etkinliğini gerçekleştirirken hedef dildeki gramatikal faktörleri, o dili konuşan bireyleri, toplumu, eğitim ve refah düzeyini ve de iletişim araçlarını göz önüne almakla mükelleftir. Zira tüm bunlar hedef dildeki okuyucular için çevirisi yapılacak metnin algılanışında oldukça önemli ve aktif roller üstlenmektedirler. Bununla birlikte okumakla yükümlü olan eleştirmenler de tüm bu saydığımız etkenlere dikkatini vermelidir.

'Sur' (Güney) isimli kısa öyküyü Türkçeye Fatih Özgüven kazandırmıştır. Kendisinin yaptığı çeviride öne çıkan ilk nokta başvurduğu abartılar ve kısaltmalar olmuştur. Kültürel faktörlerin fazlasıyla yoğunlaştığı Türkçe çeviri metninde başkahraman Juan Dahlmann'ın milliyetçi ruhu, ortaya koyduğu şu cümlelerde kendini belli etmektedir: 'can sıkıntısı ve yalnızlık, bütün bunlar bu yürekten fakat hiçbir zaman gösteriş̧̧i olmayan milliyetçiliği beslediler.' Kaynak metinde kullanılan 'criollismo' kavramının Türkçeye yapılan çevirisinde İspanyolca aslına sadık kalınmamıştır çünkü 'criollismo' Latin Amerika' da yaşamını sürdüren yerel halkların yaşam şartlarını ifade edebilmek adına ortaya çıkarılmış bir edebi akımdır. Çevirmenin kullandığı 'Milliyetçilik' kavramı 'criollismo'nun taşıdığı anlamı aktarmada yetersiz kalmış, kültürel aktarım sorunu gözlenmiştir. Bununla birlikte İngilizce çeviride yararlanılan 'Argentinization' kavramı Milliyetçilik kelimesinin yanında daha doğru bir çeviri hissiyatı yaratmaktadır. Nitekim İngilizce çeviriyi okuyan bir anadil konuşucusunun aklında Argentinization' kavramı daha çok şey ifade edecek ve Juan'ın hissiyatlarını bir Türk okura göre daha iyi anlayacak.

Özgüven'in kullandığı deyimler de dikkat çeken diğer kültürel faktörleri oluşturmaktadır. Çevirinin daha edebi bir hava içerisinde olması için ağdalı bir dil kullanmayı tercih etmektedir. Her bakımdan çevirmen aşağıda örneklerini vereceğimiz deyimleri kullanarak orijinal metne sağdık kalmaktansa Türkçenin zenginliğini okuyucuya sunmaktadır. Kullandığı deyimlerden bazıları şunlardır: elinde tutmak, gözleri kamaşmak, gözyaşına boğulmak, talihi dönmek, tadını çıkarmak, demir atmak, kavgaya sürüklenmek, kafası cilalanmak, meydan okumak, küfür savurmak, bıçak sallamak.

\section{Şekil 1}

Kültürlerin Buluşması

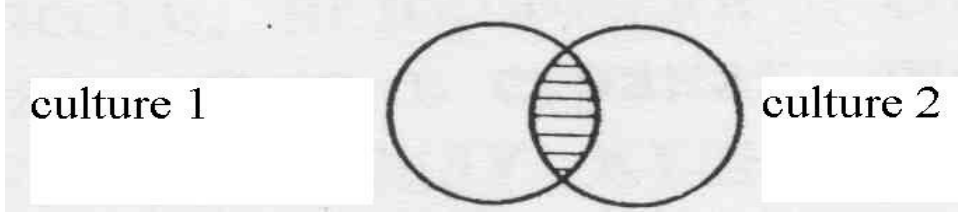

Kaynak: Logos Group (2014). Translation loss: cultural factors, http://courses.logos.it/EN/4_9.html 
Anton Popovič’e göre bir çevirinin sahip olduğu kaynak ve erek kültürler kısmı olarak birbirleriyle örtüşürler. Çevirmenin çevirisinde ortaya koyduğu üslubu aslında metnin yazarının bireysel ve kolektif kültürlerinin bir karışımıdır. Dilbilimsel çeviride bu çelişki belirgindir; çünkü iki kültürün, hedef ve kaynak metinlerin buluşmasıdır (Popovič, 1975, s. 33).

Popovič́in görüşüne göre, kültürler arasındaki bu çelişkilerin patlak vermesinde üç farklı durum çizmek mümkündür. Bunlardan ilki merkeze doğru olan, ikincisi ise merkezkaç baskısıdır. Sonuncu ise ilk ikisinin bir karışımıdır.

\section{Şekil 2}

\section{Kültürlerin Birleşimi Sonucu Oluşan Üç Farklı Durum}

1.

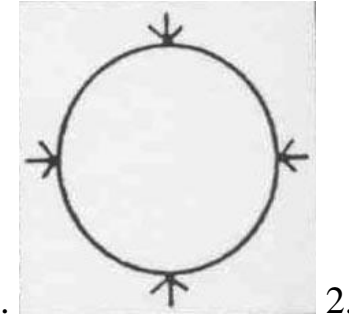

2.

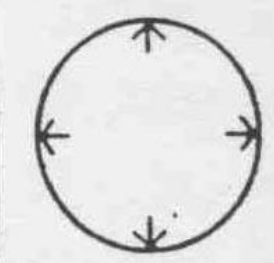

3.

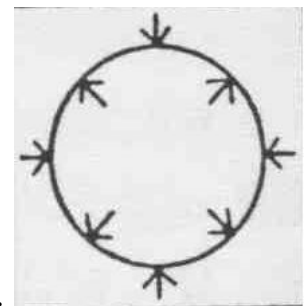

Kaynak: Logos Group (2014).

Özgüven'in çevirisinde hem merkeze doğru hem de merkezden uzaklaşan bir tutumun söz konusu olduğunu görüyoruz. Gaucholar ile ilgili bölümde merkeze doğru yapılan bir çeviri tablosu çizerken, criollismo'nun geçtiği kısımlarda merkezden uzaklaşan bir çeviriye tanıklık ediyoruz çünkü Arjantinli olmanın öneminin vurgulandığı bu bölümlerde kaynak kültürün belli başlı özelliklerinin yerini okuyucunun kültürüne ait unsurlar almıştır ve okunabilirlik adına orijinal metindeki kültürel kimliği kaybolmuştur. Hikâyenin İngilizce çevirisini baktığımız zaman ise tamamen merkeze doğru yapılan bir çeviri ürünü görmekteyiz. Çevirmen hem lengüistik hem de kültürel açılardan kaynak metne daha yakın ve sadık kalmayı başarabilmiştir.

Açıklamalar ve çıkarmalar hem Türkçe hem de İngilizce çevirilerde ihtiyaç gereği yapılmıştır ve bunlar da kültürel ve sosyal etkenler neticesinde başvurulan yöntemlerdir. Constitución tek başına Arjantin'de bir meydan olarak bilinmesine ve kaynak metinde tek başına kullanılmasına rağmen, Türkçe çeviride Constitución Meydanı; İngilizce çeviride ise Plaza Constitución eklemeleri yapılmıştır. Elbette çevirmenlerin, okuyucu kitlesinin bahsi geçen yer ile ilgili fikir sahibi olmaları adına yaptıkları bu eklemeleri iyi niyet gösterisi olarak kabul edebiliriz.

Türkçe ve İngilizce çevirilere pragmatik bir yaklaşımla bakacak olursak kaynak metnin vermeye çalıştığı izlenimleri yansıtan cümleler bulunmaktadır. Hikâyenin sonuna doğru çocuklardan birinin Juan Dahlmann'1 düelloya davet ettiği bölümde sarf ettiği 'Vamos saliendo' cümlesi tehditkâr bir cümledir ve her iki dilde de 'Hadi, işimize bakalım' ve 'Let's go outside' çevirileri ile bu tehditkâr havayı yakalayabilmişlerdir.

Özgüven'in çevirisinde yararlandığı bir diğer yöntem ise kültürel ödünçleme yolu olmuştur.

Kültürel öğelerin aktarımında takip edilebilecek bir dizi stratejinin en uç noktalarında bulunan yabancılaşma ve yerlileştirme işlemlerinden korunmak için birinci alternatif, kaynak dildeki ifadenin aynısını hedef dile aktarmaktır. Bu yolla yabancı bir öğe, hedef metne herhangi bir uyarlamaya tabi tutulmadan aktarıldığı için de doğal olarak 'egzotik' kalmış olur (Suçin, 2013, ss. 212-213).

Eski bir kılıç, ifadesiz yüzlü, sakallı bir adamın daguerrotype'ini içeren deri bir çerçeve, belli müziklerin afra-tafrası ve zerafeti... cümlesindeki daguerrotype kelimesini direkt olarak İngilizce çeviriden ödünç almış ve kaynak metin dizgesinden erek metin dizgesine aktarılmıştır. Bir başka ödünç alma stratejisi çiftlik çalışanı anlamına gelen 'peon' kelimesi ile yapılmıştır ve '. . .bu kez peoneler açı $k c ̧ a$ güldüler.' şeklinde aktarılmıştır. 
Ortaç, $\mathcal{N}$. (2021). Sosyal ve kültürel faktörlerin etkisi altında Jorge Luis Borges'in "If Sur" (Güney) isimli kisa öyküsünün Türkçe ve ingilizce çevirilerinin karşılaştırmali çözümlemesí.

Dilbilimsel sorunsallara baktığımızda sıklıkla karşılaştığımız bir diğer husus ise sözdizimi tutarsızlığı olmuştur. Çevirmen Türk okuyucular için daha anlamlı olması açısından cümleleri bölerek çeviri yapmayı uygun görmüştür: 'Ele geçirdiği inceleme arzusuyla dopdolu, asansörü beklemeden merdivenleri tırmanmaya başladı. Karanlıkta alnına bir şey sürtündü...', 'Kendini mutlu ve konuşkan hissetti. Gidecekleri yere vardıklarında, onu soydular, saçını kazıdılar...' İspanyolca metinde cümleler bağlaçlarla bağlanırken, kendi dilimizde karışıklığa mahal vermemek açısından cümleler bölünerek bizlere sunulmuştur. İncelemeye değer gördüğümüz bir diğer husus da kullanılan zaman kavramlarıdır. Çeviri metinden örneklere bakmamız gerekirse: 'Karanlıkta alnına bir şey sürtündü; yarasa mıydı, kuş mu? ve 'Belki de kullanmasını bilmediği bıçağını sıkıca kavrayarak, Dahlmann ovaya doğru yürüdü.' Özgüven çevirisinde geçmiş zaman kullanma eğiliminde olsa da kaynak metinde yer alan bu cümleler geniş zamanda yazılmıştır; çevirmen bu bağlamda günümüzden çok uzak bir zamanda olup bitmiş bir olaya vurgu yapmak istemiş olabilir.

Hikâye içerisinde yer alan bazı cümleleri kaynak metin ve çevirileriyle karşılaştırma yapacağımız bu bölümde İngilizce ve İngilizcesinden Türkçeye çevirisi yapılan hedef metinleri inceleyeceğiz.

KM: El hombre que desembarcó en Buenos Aires en 1871 se llamaba Johannes Dahlmann y era pastor de la Iglesia evangélica; en 1939, uno de sus nietos, Juan Dahlmann, era secretario de una biblioteca municipal en la calle Córdoba y se sentía hondamente argentino.

İÇ: The man that stepped off the boat in Buenos Aires in 1871 was a minister of the Evangelical Church; his name was Johannes Dahlmann. By 1939, one of his grandsons, Juan Dahlmann, was secretary of a municipal library on Calle C6rdoba and considered himself profoundly Argentine.

TÇ: 1871'de Buenos Aires'e ayak basan adam Johannes Dahlmann adını taşıyordu ve bir Protestan rahibiydi. 1939'da Córdoba Sokağı'ndaki bir belediye kütüphanesinde sekreter olan torunlarından biri ise Juan Dahlmann adını taşıyordu ve kendisini bütünüyle Arjantinli sayıyordu.

Kaynak metinde sıralı cümleler kullanılırken, İngilizce ve Türkçe çevirilerde cümleler bölünerek aktarılmıștır. İspanyolcada kullanılan 'hondamente' kelimesi ‘derinden' anlamını vermekte; kendisini derinden Arjantinli hisseden bu adamın İngilizce çevirisini 'profoundly' olarak doğru verilmiş iken Türkçe çeviride değiştirme stratejisi kullanılarak 'bütünüyle' kelimesi tercih edilmiştir. Ancak anne tarafindan Arjantinli baba tarafindan Alman olan Juan Dahlmann'ın kendisini sadece ve sadece Arjantinli hissettiğini vurgulamak için kullanılan 'bütünüyle' ifadesi 'derinden' kelimesinin güçlü anlamını taşımamaktadır. Yine, İspanyolca metinde kullanılan ve 'hissediyordu' anlamını veren 'se sentía' fiili için İngilizce çeviride kendisini Arjantinli olarak görürdü kullanımı karşımıza çıkmaktadır. Türkçe çeviride 'sayıyordu' ifadesini kullanması soy isim olarak baba tarafını seçmesine rağmen kendisini bu denli Arjantin'le özdeşleştiren bir adamın hissiyatlarını karşılamada hem anlam kargaşası yaratmış hem de doğru bir çeviri olmamıştır.

KM: ...Dahlmann había logrado salvar el casco de una estancia en el Sur, que fue de los Flores: una de las costumbres de su memoria era la imagen de...

İÇ: ... Dahlmann had managed to save the shell of a large country house in the South that had once belonged to the Flores family; one of the touchstones of his memory...

TÇ: Dahlmann, ... Flores ailesine ait Güney'deki bir çiftliğin dört duvarını elinde tutmayı başarmışt1... hiç gözünün önünden gitmezdi.

İspanyolcada kullanılan 'estancia' kelimesi özellikle Latin Amerika'da hem büyük müstakil evleri tanımlamakta hem de çiftlik anlamına gelmektedir. İngilizce çeviride 'büyük bir kır evi' ifadesi tercih edilirken Türkçe çeviride 'çiftlik' kullanılması uygun görülmüştür. Los Flores ifadesi ise Flores Ailesi anlamına gelmekte ve her iki çeviride de İspanyolca metinde olmamasına rağmen 'aile' ve 'ait' kelimeleri eklenmiştir. Bu eve ait güzel anıları olan Dahlmann'ın hafızasında yer eden bu ev/çiftliğin İngilizce çevirisinde değiştirme yoluna giderek mihenk taşı anlamına gelen 'touchstone' kelimesi kullanılırken, Türkçe çeviride 'gözünün önünden gitmezdi' deyimi kullanılmış ve kaynak metindeki anlam karşılanmıştır. 
Fatih Özgüven'in Türkçe çeviride en fazla başvurduğu yöntemlerden biri deyimlerin sıklıkla kullanımı olmuştur. Elinde tutmak, gözünün önünden gitmemek, avunup durmak, bitkin düşmek, gözleri kamaşmak, başı dönmek, gözyaşlarına boğulmak, hatırına gelmek, aklından geçirmek, mani olmak, tanıdık gelmek, tadını çıkarmak, karar vermek, demir atmak, aldırış etmek, işe yaramak, meydan okumak, ayağa kalkmak. Sıklıkla kullanılan bu deyimler hem Türkçemizin zenginliğini hem de çevirmen Fatih Özgüven'in Türkçeye ne kadar hâkim olduğunun birer göstergesidir.

Sürekli eline aldığı Binbir Gece Masalları kitabını bir türlü okumaya fırsat bulamıyor ve bunu her iki çeviride de yaşadığı sıkışmışlık çerçevesinde hissediyoruz. Dikkat çekilmesi gereken nokta kitabın ismi İngilizce çeviride Arabian Nights olarak karşımıza çıkmaktadır; hikâyenin İngilizcede yapılan diğer çevirilerinde One Thousand and One Nights olarak da kullanıldığını gördük, ele aldığımız çeviride çevirmen ilk belirttiğimiz halini kullanmayı tercih etmiştir.

\section{Sonuç}

Toury'e göre kaynak metne sadık olan çeviriler yeterli; erek kültüre ve dile uyumlu yapılan çeviriler kabul edilebilir görülmüsşür. Bu açıklama 1şığında hikâyenin Türkçe çevirisi için kabul edilebilir İngilizcesi için ise yeterli demek uygun olacaktır. Zira Türkçe çeviride Türk okurun olayları daha rahat anlayabilmesi, Borges'in mesajlarını kavrayabilmesi için günlük konuşma diline yakın ifadeler seçilmiş, deyimlerin çokça kullanımı; ekleme, çıkarma, değiştirme ve ödünç alma stratejilerine başvurmuş olması bunun kanıtı niteliğindedir. İngilizce çeviriye geldiğimiz zaman kaynak metne oldukça sadık kalışı yeterli olarak nitelendirilmesine sebep oluyor, cümle dizilimlerinin benzerliği; Latin Amerika'yı simgeleyen öğelerin orijinaline yakın ve uygun ifadelerle verilmiş olması onu daha sadık kı1mıştır, kaynak kültür erek kültürde yabancılaşmamıştır.

Borges bilgiye âşık, kararlılık ve tutkuyla çalışmalarını gerçekleştiren ve derinliği olan bir yazar ve düşünürdür. Tüm bunlar göz önünde bulundurulduğunda İngilizce çevirinin kaynak metindeki duyguyu en baştan sona yansıttığına şahit oluyoruz. Bununla birlikte, Türkçe çeviri hikâyenin duygusal öğelerini başarılı bir şekilde sunarken, yerelleştirme unsurları ağır bastığı için Borges'in fiziksel ve ruhsal beden arasında kahramanın gelgitlerini, kaderi ve aslında olmasını istediği gerçekleri aktarmada geri planda kalmıştır.

Hikâyedeki gibi Latin Amerika ülkelerinde yaşayan yerel halkların da bulunduğu çokkültürlü ortamlarda kültürlerarası iletişimi sağlamak önem arz eden ve belki de üzerinde çok çalışılmamış bir alandır. Çeviri, kültürlerarasılığın sağlanması için diyalog kurma görevi üstlenen bir arabulucu olarak ortaya çıkar ve başkahraman olur. Bu bağlamda çeviri işini gerçekleştiren çevirmen, çeviriyi oluşturan bileşenleri ve işlevselliğini iyi kavramalıdır. Çeviri metni beden ise, çevirmen de onun kanıdır.

İletişim, devam edebilmek için nasıl ki en az iki kişiye ihtiyaç duyuyorsa, çeviri de en az iki dil, iki farklı kültür hatta çokkültürlü toplumlara gereksinim duyar. Bu yüzden çevirinin söz konusu olduğu yerde kültürlerarası etkileşim ve dönüşüm de zaruridir.

\section{Araştırmanın etik yönü}

$\mathrm{Bu}$ araştırmanın etik kurul izni gerektirmeyen araştırmalardan olduğunu beyan ederim.

\section{6. Çıkar çatışması beyanı}

Çalışmanın sonuçları veya yorumları etkileyebilecek herhangi bir maddi veya diğer asli çıkar çatışması olmadığını beyan ederim.

\section{Katkı oranı}

Çalışmanın tüm aşamaları yazar tarafından tasarlanmış ve hazırlanmıştır. 
Ortaç, $\mathcal{N}$. (2021). Sosyal ve kültürel faktörlerin etkisi altında Jorge Luis Borges'in "El Sur" (Güney) isimli kisa öyküsünün Türkçe ve ingilizce çevirilerinin karşılaştırmalı çözümlemesí.

\section{NOTLAR}

1. Çevirilerini incelediğimiz bu hikâyenin İngilizce çevirileri birden fazladır, dolayısıyla Fatih Özgüven'in hangi versiyonu kullanarak Türkçe çevirisini gerçekleştirdiğini bilmiyoruz.

2. Gaucho Arjantin, Uruguay ve Brezilya'nın güneyinde köylü halkı tanımlamak için kullanılan bir terimdir. Türkçe çeviride gaucho kelimesi 'goşo' olarak kullanılmıştır.

3. Criollismo: XIX. yüzyılın sonlarında XX. yüzyılın başlarında Latin Amerika'da ortaya çıkan edebi bir akım. Bu edebi akım Latin Amerika'da yaşayan yerel halkların (gaucholar, indiolar ve negrolar) yaşamlarını betimlemede realizmin önemine vurgu yapar ve karakterize olur.

4. Daguerrotype eski bir fotoğraf tekniğidir, dagerreyotipi olarak da bilinmektedir. Çevirmen bu şekilde kullanmak yerine İngilizcesini olduğu gibi almayı tercih etmiştir.

5. KM: Kaynak Metin

İÇ: İngilizce Çeviri

TÇ: Türkçe Çeviri 
Kayseri Üniversitesi Sosyal Bilimler Dergisí Cilt 3, Say1: 1, Haziran 2021, 1-9

Kayseri University Journal of Social Sciences. Vol 3, No: 1, June 2021, 1-9

\section{KAYNAKÇA}

Kristal, E. (1999). Borges y la traducción. Lexis, 23(1), 3-23.

Limón Aguirre, F. (2013). Interculturalidad y traducción. Retos al entendimiento y la comunicación. Tinkuy, 20, 92-100.

Logos Group (2014). Translation loss: cultural factors, http://courses.logos.it/EN/4_9.html, Erişim Tarihi: 16.05.2019.

Marín-Lacarta, M. (2008). La traducción indirecta de la narrativa china contemporánea al castellano: ¿síndrome o enfermedad? Revista de Historia de la Traducción, 2, http://www. traduccionliteraria.org/1611/art/marin.htm

Popovič, A. (1975). Teória umeleckého prekladu, Bratislava.

Ruiz Pérez, P. (1986). Borges, hacedor de ficciones: una guía del laberinto, Cuenta y Razón, 25, 113130.

Saénz, M. (2009). Traducción y cultura en el ámbito literario, Entreculturas, 1, 763-771.

Suçin, M. H. (2013). Öteki dilde var olmak, Say Yayınları.

Taş, S. (2017). Kültürel unsurların çevirisi ve çeviri stratejileri, Humanitas, 5(10), 1-14.

Toury, G. (1995). The nature and role of norms in translation, John Benjamins Publishing.

Tymoczko, M. (1995). The metonymics of translating marginalized texts, Duke University Press, 47(1), $11-24$.

Tymoczko, M. (2007). Enlarging translation, empowering translators, St. Jerome Publishing. 